patients $(17.7 \pm 1$ and $49.2 \pm 5.55$ respectively), when $\mathrm{Vd} 2$ cell population were cultured in presence of DMAPP.

Conclusion Our observations indicate that $\mathrm{Vd} 2$ activation is correlated with $\mathrm{BD}$ progression. It is of interest the involvement of $\mathrm{Vd} 2$ lymphocytes in active disease and the absence of response to phosphoantigens in vitro in patients in complete remission. Further definition and effector functions of the $\mathrm{Vg} 9 / \mathrm{Vd} 2$ cells are required to improve their role in the maintenance of activity disease. In addition, the inhibition of gd activation and therefore of the pro-inflammatory CK production may provide an interesting therapeutic strategy for the novel treatments for BD

\section{FRI0167 CLINICOPATHOLOGIC EVALUATION OF NODULAR LESIONS OF BEHÇET'S DISEASE}

${ }^{1} \mathrm{C}$ Demirkesen, ${ }^{1} \mathrm{~N}$ Tüzüner, ${ }^{2} \mathrm{C}$ Mat, ${ }^{3} \mathrm{M}$ Senocak, ${ }^{4} \mathrm{~N}$ Büyükbabani, ${ }^{2} Y$ Tüzün, ${ }^{5} \mathrm{H}$ Yazici. ${ }^{1}$ Pathology; ${ }^{2}$ Dermatology; ${ }^{3}$ Biostatistic; ${ }^{4}$ Pathology, Istanbul Medical Faculty, Istanbul, Turkey; ${ }^{5}$ Internal Medicine, Division of Rheumatology, Cerrahpasa Medical Faculty, Istanbul University

\subsection{6/annrheumdis-2001.227}

Background Among the cutaneous manifestations, nodular lesions are rather common in Behçet's disease (BD).

Objectives The histologic nature of these lesions has been a matter of controversy.

Methods In order to establish their distinguishing features, biopsies taken from nodular lesions of 24 patients with BD, 25 with nodular vasculitis (NV), and 20 with erythema nodosum (EN) were compared.

Results Statistical analysis revealed that there was insignificant difference between BD and NV. However, neutrophil predominating infiltrate in the subcutis was more common in $\mathrm{BD}$, while necrosis and granuloma formation were encountered more frequently in NV. On the other hand, there was a statistically significant difference between BD and EN. Septal panniculitis, lymphocyte predominating infiltrate, absence of many vascular changes as well as vasculitis, and necrosis were features in favour of EN.

Conclusion EN-like lesions of BD are mainly neutrophilic vascular reactions with accompanying changes in subcutis. Their histology are more similar to NV than EN. Thus suggests that these nodular lesions of $\mathrm{BD}$ may, indeed be due to vasculitis. On the other hand, the histologic feature of these nodular lesions has enough specificity to differentiate them from EN due to other causes.

?Copyright (C) 2001 by the American Society of Clinical Pathologists. Reprinted by Permission?

\section{FRI0168 LONGTERM THERAPY IN TEMPORAL ARTERITIS: ANALYSIS OF ADVERSE EFFECTS}

C Resende, JE Fonseca, H Canhão, JC Teixeira Costa, JA Pereira Silva, M Viana Queiroz. Rheumatology Unit, Santa Maria Hospital, Lisbon, Portugal

\subsection{6/annrheumdis-2001.228}

Background Temporal arteritis (TA) is a serious disease and require a prolonged period of steroid therapy.

Objectives With the aim of clarifying if steroid cumulative dose is a significative risk factor for adverse effects, we performed a study of 20 TA patients, attending the rheumatology out-patients clinic of Santa Maria Hospital, Lisbon, with a minimum followup time of 2 years.
Methods

Results The mean follow-up period was $84.3 \pm 28.9$ months. 12 patients were female $(60 \%$, mean age at the time of diagnosis of $69.4 \pm 8.6$ years) and 8 were male $(40 \%$, mean age at the time of diagnosis of $64.6 \pm 7.7$ years). All the patients were treated with prednisone (PDN), 2 with $3 \times 1000 \mathrm{mg}$ methylprednisolone pulses and 4 with concomitant immunosupressors (3 azathioprine and 1 cyclophosphamide). The mean initial PDN dose was 53,2 mg. The PDN dose was tapered and the mean doses were: 1 st month $-49,9 \pm 18,7 \mathrm{mg}$; $3 \mathrm{rd}$ month ? $34,0 \pm 19,1$ $\mathrm{mg}$; 6th month ? $24,9 \pm 17,7 \mathrm{mg} ; 12$ th month ? $10,5 \pm 7,8$ mg; 24th month ? 5,9 $\pm 3,2 \mathrm{mg} ; 36$ th month ? 5,6 $\pm 3,2 \mathrm{mg}$; 60 th month ? $7,8 \pm 8,6 \mathrm{mg} ; 84$ th month ? $5,3 \pm 2,8 \mathrm{mg}$.

By the end of the first 6 months $50 \%$ of the baseline dose was reached and after 2 years all patients were on a maintenance low dose $(5.9 \mathrm{mg}) .2$ patients $(10 \%)$ were able to stop the PDN (at 48 and 55 months). The mean cumulative PDN dose was $17641,8 \pm 8937,3 \mathrm{mg} .17(85 \%)$ patients had corticosteroid related adverse effects. Although these patients had a mean cumulative PDN dose $(19064,2 \pm 8880,7 \mathrm{mg})$ superior to the dose of the patients without adverse effects (9575 \pm 3401,5 $\mathrm{mg}$ ), the difference was not statistically significative. The mean cumulative PDN dose for each of the observed adverse effects is characterised in the next Table 1.

\begin{tabular}{llll} 
Abstract FRI0168 Table 1 & & & \\
\hline & $\mathrm{n}$ & PDN dose $(\mathrm{mg})$ & $\mathrm{p}$ \\
\hline Hypertension/Without Hypertension & $10 /$ & $18586,6 /$ & NS \\
& 10 & 16695,0 & \\
$\begin{array}{l}\text { Hypercholesterolemia/Without } \\
\text { Hypercholesterolemia }\end{array}$ & $8 / 12$ & $20343,8 /$ & NS \\
Hyperglycemia/Without Hyperglycemia & $5 / 15$ & 275838,8 & \\
& & 14379,8 & $<0,01$ \\
Hypertriglyceridemia/Without Hypertriglyceridemia & $3 / 17$ & $25550,0 /$ & NS \\
& & 16245,0 & \\
Osteoporosis/Without Osteoporosis & $8 / 12$ & $20941,4 /$ & NS \\
& & 15440,4 & \\
Cataract/Without Cataract & $3 / 17$ & $27681,3 /$ & $<0,05$ \\
& & 15868,9 & \\
\hline
\end{tabular}

Conclusion Our results suggest that PDN cumulative dose is a major factor in the induction of hyperglycemia and cataracts. All the others adverse effects had a trend to be correlated with higher PDN doses but this observation did not reach a statistically significative difference.

\section{FRI0169 CYCLOSPORIN A VERSUS ÝNTERFERON ALFA IN TREATMENT OF SEVERE OCULAR INVOLVEMENT OF BEHÇET'S DISEASE}

A Dýnc, S Pay, Z Bayraktar, H Erdem, M Turan. Rheumatology and Ophtalmology, Gülhane School of Medicine, Ankara, Turkey

\subsection{6/annrheumdis-2001.229}

Background Sight-threatening uveitis is a well-known complication of Behçet's Disease in which recurrent oral and genital aphthous ulcerations, arthritis, neurologic, and vascular involvement also frequently accompanied. 